\title{
Pre-service English Teachers` Views on Digital Literacy Competences in Language Teaching
}

\author{
Yentri Anggeraini ${ }^{1}$, Abdurrachman Faridi ${ }^{2}$, Januarius Mujiyanto ${ }^{3}$, Dwi Anggani Linggar \\ Bharati $^{4}$ \\ \{ $\underline{\text { anggeraini.yentri@yahoo.com }}{ }^{1}$ \}
}

Universitas Baturaja Sumatera Selatan ${ }^{1}$, Universitas Negeri Semarang ${ }^{2,3,4}$

\begin{abstract}
Teaching in digital era allows the pre-service teachers to build their digital literacy to run digital teaching effectively and efficiently. Digital literacy on language teaching is the ability to select, evaluate, operate and apply digital media and digital tools in teaching and learning process. This current study aimed at investigating the pre-service English teachers`views on digital literacy competences in language teaching. Survey research was conducted to gather the data and 67 pre-service English teachers were as the participants. The data taken from questionnaire were analyzed through percentage analysis. The finding indicated that the pre-service English teachers were in average digital literacy competences, $84 \%$ of them were familiar with social media, $87 \%$ of them argue that digital literacy competences as one of important things in digital teaching, $70 \%$ of them were familiar with digital media for EFL teaching. As the conclusion, the pre-service English teachers still need the professional training to upgrade their digital literacy competences and face the digital teaching.
\end{abstract}

Keywords: Digital Literacy, Language Teaching, Digital Teaching

\section{Introdution}

The technology changing allows the teacher to provide it as tools/media in teaching and learning process. [1] reviewed the technology in English language and literature learning activities and internet communication in use and there were about web based learning tools such as email, weblogs, instant messenger, mobile devices, and IPODS. For example by using the email, English teacher can take some benefit from websites which include e-mail accounts like Yahoo, Hotmail, and Gmail. So, the teachers can make topic discussion and send it to the students via e-mail when receiving the e-mail students start to write compositions or essays in English and discuss a work and then send back to the teacher. Meanwhile, [9] found that $32 \%$ of the $505 \mathrm{~K}-8$ teachers use games $2-4$ days per week, whereas $18 \%$ use them every day, $70 \%$ of the teachers agree that using digital games increases motivation and engagement with content/curriculum. To sum up, playing games to learn, teachers and students can also collaboratively share learning to playing games. [12] stated that educators are more likely than are members of the general public to use technology tools such as smartphones and tablet computers; $54 \%$ of teachers and $70 \%$ of administrators use smartphones for working, $52 \%$ of teachers and principals have provided an online class for the training purposes. Furthermore, [16] proposed that new literacies are the abilities a person or social group draws upon when interacting with digital technologies to derive or produce meaning, and the social, learning and 
work-related practices that these abilities are applied to. [5] analysed the components of digital literacy based on its definition - the skills, knowledge and understanding that enables critical, creative, discerning and safe practices when engaging with digital technologies in all areas of life. The components consist of creativity, critical thinking and evaluation, cultural and social understanding, collaboration, the ability to find and select information, effective communication, e-safety and functional skills. Meanwhile, [2] found out that the English lecturers provide has intermediate literacy abilities dealing with classroom practices such as providing social media, blogging, email , and online learning to teaching and learning process. In sum up, the main point is how the teachers provide the digital technologies well and give the positive effect of the English and teaching practice.

Digital literacy is described as creating social mores within individuals' private lives and the ability to reflect on this process using digital tools appropriately. [13] stated that digital tools become one of important parts of people's lives and also increased three meaningful factors such as speed, virtuality, and networking. In addition, [8] argued that there is no need to search for similarities and differences with other types of literacy among media literacy, information literacy and digital literacy. The important thing is how the new literacy can be consumed based on the need. Furthermore, [11] conducted a survey research on digital literacy competences and learning habit of to 20.172 open and distance learners and the result revealed that most of the participants were in basic competences level.

The survey focused on the digital habits of learners was conducted by previous works such as [14]:[4]: [3]: [6], [7] : [11] . Moreover, [10] did a study in order to explore the development of Australian Aboriginal Pre-service teachers' digital literacy and understanding of digital pedagogies for teaching literacy. It can be concluded that the lecturing staff and the pre-service teachers need more practical workshops with hands on experience with new technologies such as interactive whiteboards. Even so, pre-service teachers can develop digital pedagogies to teach literacy by combining theories about teaching literacy with the theory and practice of using new technologies in their practicum teaching. It is important to teacher education program to be aware of the quality and competence of the graduates to face the industry era 4.0 .

The purpose of this research is to explore the pre-service English teachers'views on digital literacy competences in language teaching. By exploring the pre service English teachers' views on their digital literacy competences, the result can give some significant results. The first, theoretically, the students delivered their views on digital literacy competences that provide them to develop their digital literacy in order to be more digitally literate. The second, practically, it can support the pre-service English teachers to be professional in teaching, especially in providing the digital tools in the classroom. The last, pedagogically, it can give recommendation for the pre-service teachers in order to reflect about how important the digital literacy to face the industry ere 4.0. For the institution, it can give the contribution to never stop supporting the pre-service teachers to apply and improve the quality of the teaching and learning process in the digital era and the result of this research can be used as the evaluation for providing the courses and teaching activities deal with digital teaching. 


\section{Method}

This survey research was conducted in English education study program, Universitas Baturaja and participant was 67 pre- service English students. To gather the data, the researchers delivered the questionnaire that had been validated by five expert judgments. The source of data is described on the table 1:

Table 1. The Source of Data

\begin{tabular}{cclc}
\hline RQ & The Source of Data & Role & $\begin{array}{c}\text { Techniques for } \\
\text { collecting the } \\
\text { data }\end{array}$ \\
\hline $\begin{array}{c}\text { How were the pre- } \\
\text { service English } \\
\text { teachers`views on } \\
\text { digital competences } \\
\text { in digital teaching? }\end{array}$ & Students & $\begin{array}{l}\text {-The pre-service answered the } \\
\text { questionnaire and the result was } \\
\text { analyzed }\end{array}$ & Questionnaire \\
\hline
\end{tabular}

\section{Result and Discussion}

\section{Questionnaire Result of Pre-service English Teacher on Digital Literacy Section I}

Table 2. Digital Literacy Competences

\begin{tabular}{|c|c|c|c|c|c|}
\hline & $\begin{array}{l}\text { Very } \\
\text { Low }\end{array}$ & Low & Average & High & $\begin{array}{l}\text { Very } \\
\text { high }\end{array}$ \\
\hline \multirow{3}{*}{$\begin{array}{l}\text { Basic Digital Literacy Ability } \\
\text { Ability to use Microsoft Office } \\
\text { (MS-Word, Excel, PowerPoint, etc) }\end{array}$} & & & & & \\
\hline & 12 & 24 & 20 & 11 & 0 \\
\hline & $18 \%$ & $36 \%$ & $30 \%$ & $16 \%$ & $0 \%$ \\
\hline \multirow{2}{*}{$\begin{array}{l}\text { Ability to operate the LCD projector, } \\
\text { sound system, etc }\end{array}$} & 11 & 24 & 20 & 11 & 6 \\
\hline & $17 \%$ & $36 \%$ & $30 \%$ & $16 \%$ & $9 \%$ \\
\hline \multirow{2}{*}{$\begin{array}{l}\text { Ability to know basic knowledge about } \\
\text { computer as well as digital literacy }\end{array}$} & 20 & 14 & 21 & 5 & 7 \\
\hline & $30 \%$ & $21 \%$ & $31 \%$ & $8 \%$ & $10 \%$ \\
\hline \multirow{2}{*}{$\begin{array}{l}\text { Ability to use the internet access } \\
\text { (wireless connection) }\end{array}$} & 5 & 10 & 21 & 21 & 10 \\
\hline & $8 \%$ & $15 \%$ & $31 \%$ & $31 \%$ & $15 \%$ \\
\hline \multicolumn{6}{|l|}{ Intermediate Digital Literacy Competences } \\
\hline \multirow[t]{2}{*}{ Ability to use online references } & 2 & 0 & 23 & 35 & 7 \\
\hline & $3 \%$ & $0 \%$ & $34 \%$ & $52 \%$ & $11 \%$ \\
\hline \multirow[t]{2}{*}{ Ability to use online browse } & 0 & 5 & 24 & 30 & 8 \\
\hline & $0 \%$ & $7 \%$ & $36 \%$ & $43 \%$ & $12 \%$ \\
\hline Ability to provide interactive video from & 2 & 2 & 54 & 3 & 6 \\
\hline YouTube & $3 \%$ & $3 \%$ & $81 \%$ & $4 \%$ & $9 \%$ \\
\hline Ability to use social media (facebook, & 0 & 0 & 5 & 56 & 6 \\
\hline whatsup, twitter, etc) & $0 \%$ & $0 \%$ & $7 \%$ & $84 \%$ & $9 \%$ \\
\hline Ability to use email & 3 & 4 & 24 & 35 & 1 \\
\hline
\end{tabular}




\begin{tabular}{lccccc}
\hline & $4 \%$ & $6 \%$ & $36 \%$ & $52 \%$ & $2 \%$ \\
Ability to use blogging & 10 & 27 & 17 & 12 & 1 \\
& $15 \%$ & $40 \%$ & $25 \%$ & $18 \%$ & $2 \%$ \\
Ability to use HTML & 15 & 30 & 16 & 5 & 1 \\
& $22 \%$ & $45 \%$ & $24 \%$ & $7 \%$ & $2 \%$ \\
Ability to use web page design & 20 & 25 & 20 & 0 & 0 \\
& $30 \%$ & $37 \%$ & $30 \%$ & $0 \%$ & $0 \%$ \\
Advanced Digital literacy Ability & & & & & \\
Ability to know well about computer & 21 & 35 & 11 & 0 & 0 \\
parts and their functions & $31 \%$ & $52 \%$ & $17 \%$ & $0 \%$ & $0 \%$ \\
Ability to evaluate the downloaded & 27 & 31 & 8 & 1 & 0 \\
materials and online recourses & $40 \%$ & $46 \%$ & $12 \%$ & $2 \%$ & $0 \%$ \\
Ability to create digital storytelling & 30 & 20 & 17 & 0 & 0 \\
and others such as iMovies, moviemaker, & $45 \%$ & $30 \%$ & $25 \%$ & $0 \%$ & $0 \%$ \\
powtoon, you tube video etc as the & & & & & \\
teaching media & & & & & \\
Ability to guide others in operating a new & 45 & 17 & 5 & 0 & 0 \\
application dealing with teaching media & $67 \%$ & $25 \%$ & $8 \%$ & $0 \%$ & $0 \%$ \\
Ability to create application dealing with & 28 & 32 & 4 & 3 & 0 \\
English teaching & $42 \%$ & $48 \%$ & $6 \%$ & $4 \%$ & $0 \%$ \\
\hline
\end{tabular}

Table 2 indicated that $81 \%$ of pre-service English teachers had average ability to provide interactive video from YouTube ,88\% of them have average and high ability to use email, 84 $\%$ of them had high ability to use social media (facebook, whatsup, twitter, etc) , $83 \%$ of them had very low and low ability to know well about computer parts and their functions, $86 \%$ of them had very low and low ability to evaluate the downloaded material and online recourses, $90 \%$ of them had very low and low ability to create application dealing with English teaching.

\section{Section II}

Table 3. Digital Literacy on Language Teaching

\begin{tabular}{lcc}
\hline \multicolumn{1}{c}{ Statement(s) } & Yes & No \\
\hline English teachers must be digitally literate & 45 & 22 \\
& $67 \%$ & $33 \%$ \\
& 52 & 15 \\
Digital literacy is important to face and apply & $78 \%$ & $22 \%$ \\
digital teaching & 47 & 20 \\
& $70 \%$ & $30 \%$ \\
Digital media / digital tools facilitate the & & \\
English teachers and make learning process & & 32 \\
more meaningful and enjoyable & 35 & $48 \%$ \\
The teachers can develop their own digital & $52 \%$ & 25 \\
literacy to support digital teaching & 41 & $39 \%$ \\
The teachers digital literacy should be & $61 \%$ & \\
enhanced based on the digital technology & & \\
changing &
\end{tabular}

The table 3 indicated that from the 67 pre-service English teachers, 67\% of them argue that English teachers must be digitally literate, $78 \%$ of them argue that digital literacy is important to face and apply the digital teaching, $52 \%$ of them argue that teachers can develop 
their own digital literacy, and $61 \%$ of them argue that the teachers digital literacy should be enhanced based on digital technology changing.

\section{Section III}

Table 4. Digital Media in Language Teaching

\begin{tabular}{lll}
\hline \multicolumn{1}{c}{ Question(s) } & Dominant Participants` Answer(s) \\
\hline 1. & $\begin{array}{l}\text { Mention the media that you use } \\
\text { in your teaching practice class? }\end{array}$ & Picture, Flashcard, Video, Real \\
2. & $\begin{array}{l}\text { Mention the digital media that } \\
\text { you used in your teaching } \\
\text { practice class? }\end{array}$ & Animated Video, Photos, Facebook \\
Group
\end{tabular}

\section{Section IV}

Digital Literacy Development to Support Language Teaching

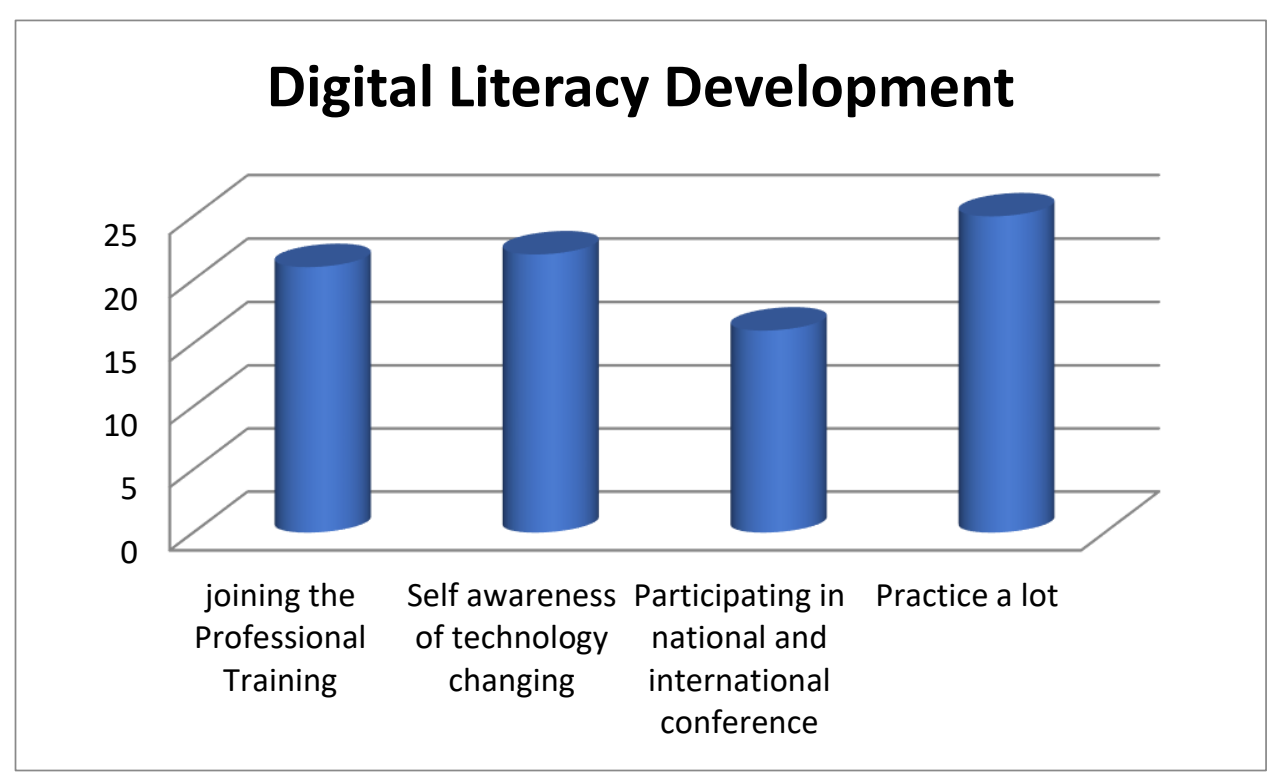

Figure 1. Digital Literacy Development

Figure 1 indicated that 21 of 67 pre-service English teachers argue that the digital literacy development can be reached by joining professional training, 22 of 67 pre-service English teachers argue that self awareness of technology changing as one of ways to be digitally literate, 16 of 67 pre-service English teachers argue that the digital literacy development can be reached by participating in national and international conference, and 25 of 67 pre-service English teachers argue that by practicing a lot as one of ways to be digitally literate. 


\section{Conclusion}

It can be concluded that the pre-service English teachers' digital literacy competences were in average level. They are already familiar with online learning and social media for communication such as facebook, whatsup, twitter, etc). In other word, they should upgrade their digital literacy competences by joining some professional training in order to face and apply the digital teaching. The result of this study can be used as the evaluation for the education program in order to facilitate the digital learning and to provide the courses and teaching activities deal with digital teaching. 


\section{References}

[1] Amiri, E : A study of the application of digital technologies in teaching and learning English language and literature. International Journal of Scientific \& Technology Research. 1(5), 103107 (2012).

[2] Anggeraini, Y., Faridi, A., Mujiyanto, J., \& Bharati, A, L, B : The teachers` perceptions on digital literacy competences in EFL classroom. Asian EFL Journal,(24)4, 5-12 (2019)

[3] Claxton, G., Powell, G. \& Chambers, M: Building 101 ways to learning power. Bristol, UK: TLO. (2004)

[4] Hadfield M., Jopling M., Royle K. \& Southern L: Evaluation of the Training and Development Agency for Schools' funding for ICT in ITT Projects. London: TDA (2009)

[5] Hague,C., \& Payton, S : Digital literacy across the curriculum. retrieved from https://www.nfer.ac.uk/publications/FUTL06/FUTL06casestudies.pdf (2010)

[6] Kay, D., McGonigle, B., Patterson, W., \& Tabbiner, B : Next generation user skills report. Sero Consulting. Retrieved from http://www.digital2020.org.uk/skills/ strands/nextgen (2009)

[7] Kerrigan, J.P : Digital literacies in transition. University of Greenwich. Retrieved from http://www2.gre.ac.uk/research/centres/ecentre/projects/dl-in-transition (2012)

[8] Koltay, T : The media and the literacies: Media literacy, information literacy, digital literacy. Media Culture \& Society, 33(2), 211-221 (2011)

[9] Levine, M., \& Millstone, J : Teacher attitudes about digital games in the classroom. New York, NY: Joan Ganz Cooney Center at Sesame Workshop. Retrieved from http://tinyurl.com/6t9jv2m (2012)

[10] Milton, M : Digital literacy and digital pedagigies for teaching literacy: Pre-service teachers` experience on teaching rounds. Journal of Literacy and Technology. 14(1), $72-97$ (2013)

[11] Ozdamar-keskin, N., Ozata, F. Z., Banar, K., \& Royle, K.: Examining Digital Literacy Competences and Learning Habits of Open and Distance Learners, 6(1), 74-90 (2015)

[12] Project Tomorrow : Mapping a personalized learning journey: K-12 students and parents connect the dots with digital learning: Speak Up 2011 National Findings. Retrieved from http://tinyurl.com/cq7lrvq (2012)

[13] Rivoltella, P.C : From media education to digital literacy: A paradigm change? In P.C. Rivoltella (Ed.), Digital literacy: Tools and methodologies for information society (pp.217-230). Hershey, PA: IGI Publishing (2008)

[14] Royle, K. \& Hadfield, M : from 'posh pen and pad' to participatory pedagogies: One story of a netbook implementation project with 108 pupils in two primary schools. International Journal of Mobile and Blended Learning, 4(1), 1-17 (2012)

[15] Solano, L. et al. : Exploring the use of educational technology in EFL teaching: A case study of primary education in the south region of ecuador', Teaching English with Technology, 17(2),77-86 (2017)

[16] Stordy, P : Taxonomy of literacies. Journal of Documentation, 71(3), 456-476. https://doi.org/10.1108/JD-10-2013-0128 (2015) 